\title{
GAUNTLET SYSTEM FOR MASTER-SLAVE MANIPULATORS
}

\author{
P. H. CHISMAR
}

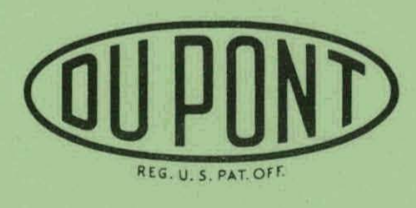

Savannah River Laboratory

Aiken, South Carolina 


\section{DISCLAIMER}

This report was prepared as an account of work sponsored by an agency of the United States Government. Neither the United States Government nor any agency Thereof, nor any of their employees, makes any warranty, express or implied, or assumes any legal liability or responsibility for the accuracy, completeness, or usefulness of any information, apparatus, product, or process disclosed, or represents that its use would not infringe privately owned rights. Reference herein to any specific commercial product, process, or service by trade name, trademark, manufacturer, or otherwise does not necessarily constitute or imply its endorsement, recommendation, or favoring by the United States Government or any agency thereof. The views and opinions of authors expressed herein do not necessarily state or reflect those of the United States Government or any agency thereof. 


\section{DISCLAIMER}

Portions of this document may be illegible in electronic image products. Images are produced from the best available original document. 
This report was prepared as an account of Government sponsored work. Neither the United States, nor the Commission, nor any person acting on behalf of the Commission:

A. Makes any warranty or representation, expressed or implied, with respect to the accuracy, completeness, or usefulness of the information contained in this report, or that the use of any information, apparatus, method, or process disclosed in this report may not infringe privately owned rights; or

B. Assumes any liabilities with respect to the use of, or for damages resulting from the use of any information, apparatus, method, or process disclosed in this report.

As used in the above, "person acting on behalf of the Commission" includes any employee or contractor of the Commission, or empluyee of such contractor, to the extent that such employee or contractor of the Commission, or employee of such contractor prepares, disseminates, or provides access to, any information pursuant to his employment or contract with the Commission, or his employment with such contractor.

Printed in USA. Price $\$ 0.50$

Avallable from the Office of Technical Services

U. S. Department of Cominerce

Washington 25, D. C. 
Engineering and Equipment

(TID-4500, 28th Ed.)

\section{GAUNTLET SYSTEM FOR \\ MASTER - SLAVE MANIPULATORS \\ by}

Paul H. Chismar

Approved by

D. E. Waters, Manager

Laboratory Operations and Services Division

March 1964

E. I. DU PONT DE NEMOURS \& COMPANY

EXPLOSIVES DEPARTMENT - ATOMIC ENERGY DIVISION

TECHNICAL DIVISION - SAVANNAH RIVER LABORATORY

AIKEN, SOUTH CAROLINA

CONTRACT AT (07-2) - 1 WITH THE

UNITED STATES ATOMIC ENERGY COMMISSION 


\section{ADSTRACT}

An improved gauntlet system was developed to reduce radioactive contamination of master-slave manipulators. The gauntlet protects the in-ccll portion of the manipulator and prevents escape of contamination through the manipulator port in the cell wall. 


\section{GAUNTLET SYSTEM FOR \\ MASTER-SLAVE MANIPULATORS}

\section{INTRODUCTION}

Increasing levels of radioactivity in the hot cells at the Savannah River Laboratory led to a need for an improved gauntlet system to protect the in-cell portions of the master-slave manipulators. Gauntlet systems in use were either difficult to install or were integral with the manipulator, so cell containment was breached and contamination was released when a manipulator was removed. For optimum service, a gauntlet should be easy to install and replace, should provide a positive seal between the cell and the operating area, and should permit the in-cell portion of the manipulator to be removed in an uncontaminated condition.

In the gauntlet that was evolved, the gauntlet is attached to the cell entry port and acts as a seal for the entry port. When the manipulator is inserted into the cell the slave end is covered; when the manipulator is removed from the cell, the gauntlet remains in place inside the cell.

\section{SUMMARY}

A gauntlet system was developed to prevent the radioactive contamination of master-slave manipulators used in hot cells. The gauntlet serves as a seal between the contaminated and clean areas, and may be installed on any containment enclosure. This gauntlet system has been adopted as the standard system for the Savannah River Laboratory for alpha and beta-gamma materials. Its use has considerably facilitated manipulator maintenance, and has improved the over-all quality of the containment of radioactive contamination.

\section{DISCUSSION}

The repair of master-slave manipulators usually requires their removal from a contaminated cell. A protective gauntlet that can be left in the cell prevents the removal of contamination from the cell and permits the manipulator to be brought into a clean area. The gauntlet also seals the manipulator entrance port into the cell.

The gauntlet system at SRL has been used successfully in ten high-level cells since November 1959. Three intermediatelevel cells are now also equipped with the same type of gauntlet. 
The Argonne-type Model 7 and Model 8 master-slave manipulators, used at the Savannah River Laboratory, are equipped with standard SRL hands ${ }^{(1)}$. The SRL master-slave hand is designed to facilitate remote installation of a gauntlet.

The SRI gauntlet system consists of two basic parts: a gauntlet and a gauntlet port (Figure 1 ).

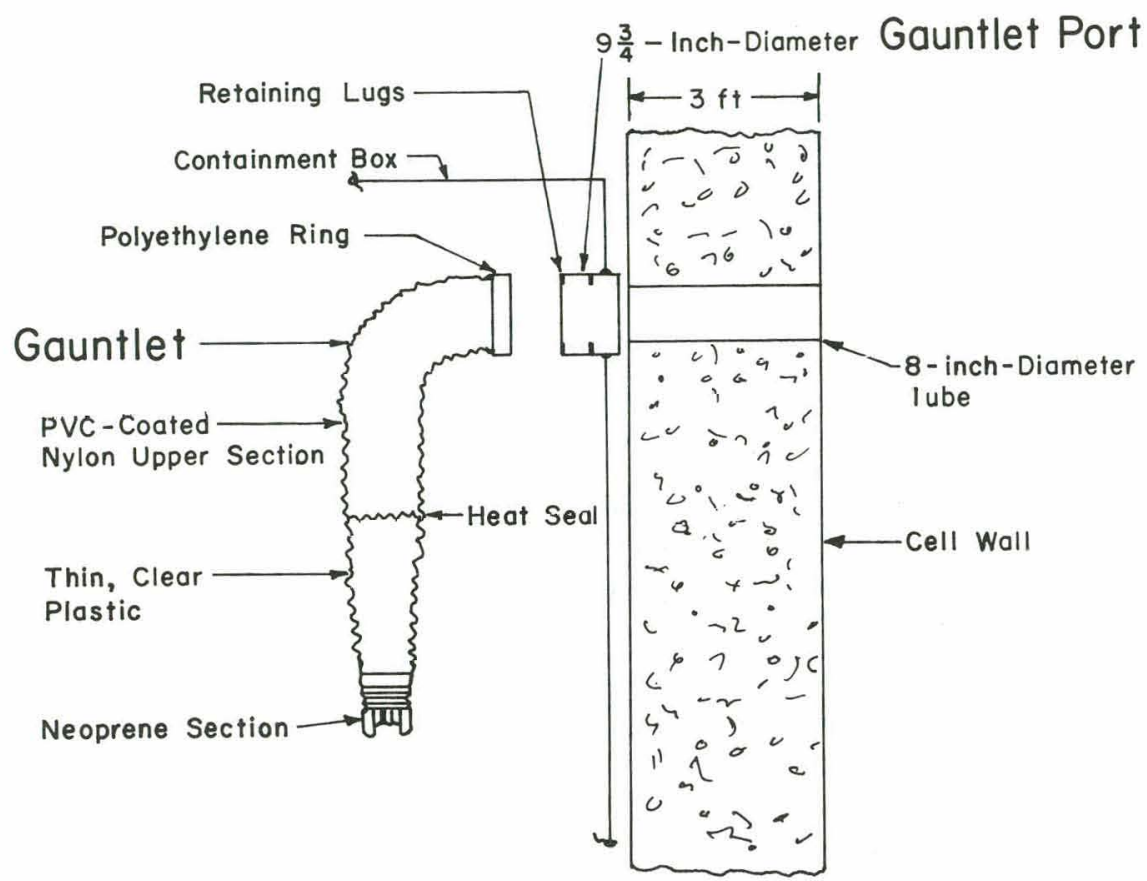

FIG. 1 GAUNTLET SYSTEM

\section{GAUNTLET}

The gauntlet consists of (1) a neoprene section that covers the hand and wrist of the manipulator and (2) plastic extensions that cover the rest of the manipulator inside of the cell.*

The neoprene section has 0-rings molded into the two end closures (Figure 2). These O-rings hold the gauntlet in place and also provide a seal. The neoprene section is convoluted to accommodate the bending motion of the wrist and the squeezing motion of the fingers. The convolutions are held away from exposed gears on the wrist by a "Micarta"** ring

(1)Leith, W. H. "Improved Master-Slave Manipulator Hand." Nucleonics 16, No. 12, 70-71 (1958).

* The neoprene and plastic sections are available from Snyder Manufacturing Co., Inc., New Philadelphia, Ohio.

* "Micarta" is a trademark of Westinghouse Electric Corp. 


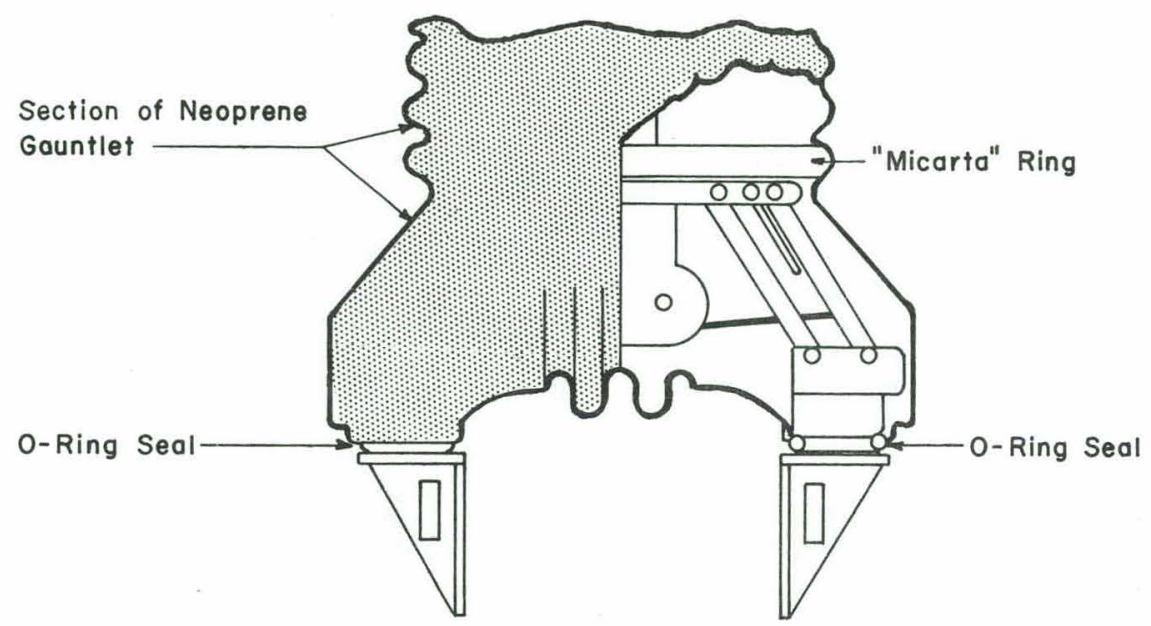

FIG. 2 GAUNTLET AND MASTER-SLAVE HAND

(Figure 2). The neoprene section is fabricated from 25-milthick latex. Sections 35 mils thick have been fabricated when greater tear resistance is needed; however, the thicker material makes the operation of the manipulator more fatiguing and decreases the "feel". The neoprene section is attached to the plastic extension with a fabric tape (Figure 3 ).

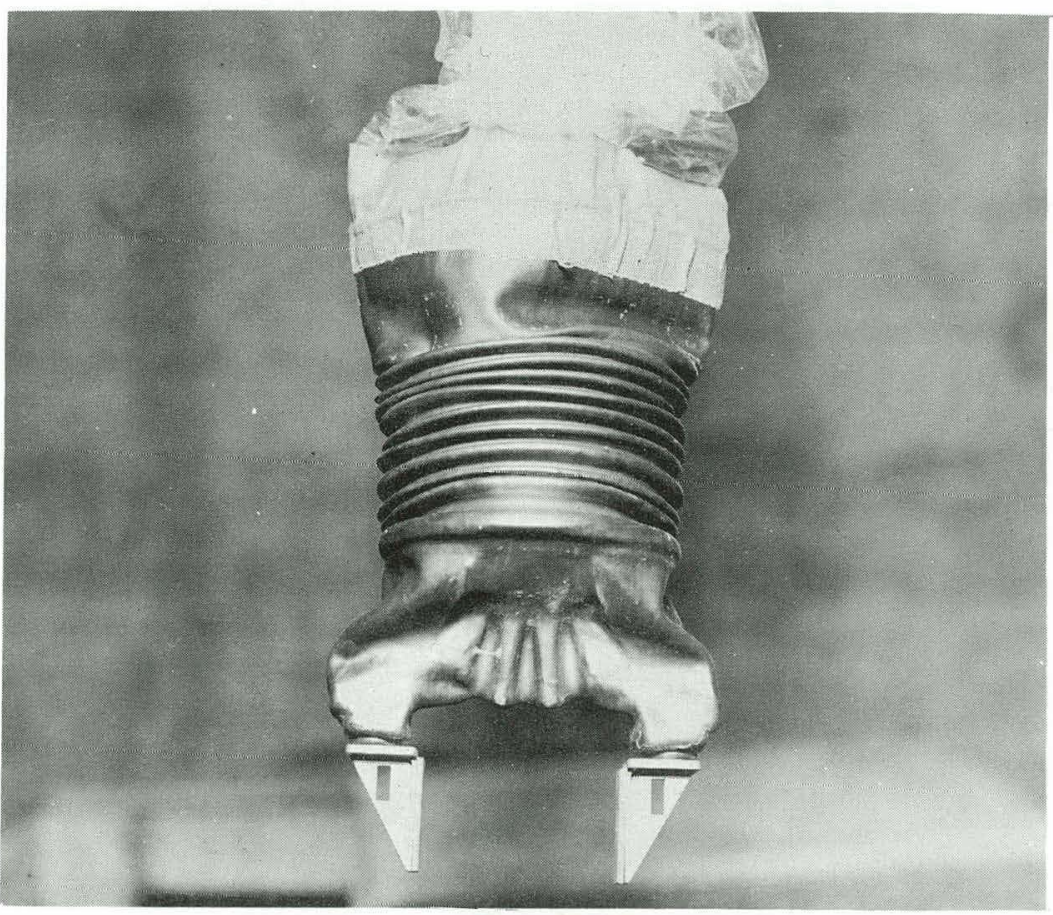

FIG. 3 NEOPRENE SECTION INSTALLED 
The plastic extension is fabricated from two sections that are sealed together. The lower section is 5-mil, clear polyvinyl chloride, and the upper section is 10-mil polyvinyl chloride reinforced with nylon mesh. The extra thickness and reinforcement prevents tearing when the manipulator is installed in the gauntlet.

A 1/4-inch-thick polyethylene ring is sewn into the upper end of the plastic extension. This plastic ring has an outside diameter that corresponds with the inside diameter of the gauntlet port. The ring seals the gauntlet in the mounting port and holds the gauntlet against the retaining lugs on the port. Figure 4 shows a Model 7 manipulator gauntlet installed in a cell.

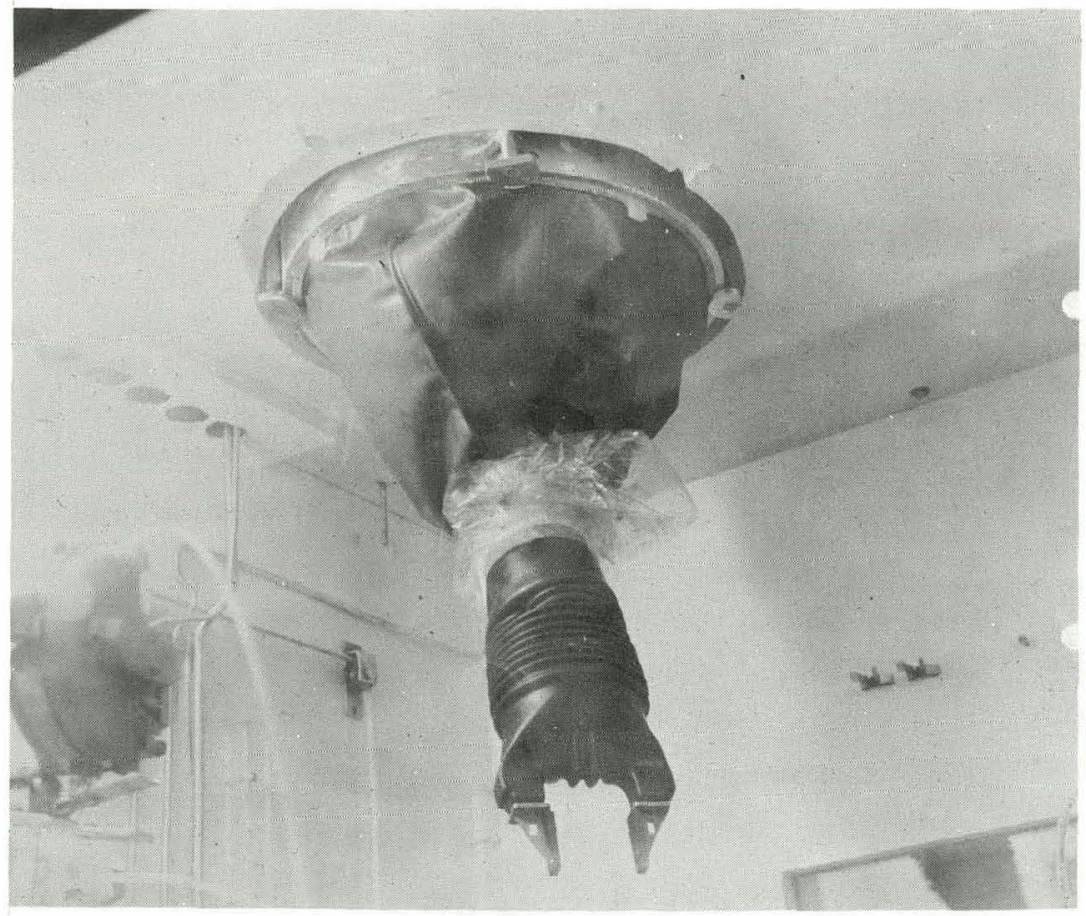

FIG. 4 MODEL 7 INSTALLATION

\section{GAUNTLET PORT}

The gauntlet port is mounted either on the cell wall or the containment box. The diameter of the port is sized to accommodate the manipulator. At SRL a 9-3/4-inch-ID port is made from a pipe section, which is machined to allow for a snug fit with the polyethylene ring on the gauntlet.

Retaining lugs are located on both edges of a standard SRL port to prevent accidental release of the gauntlet. When 
high alpha material is handled in the cells, the in-cell retaining lugs are mounted on segmented sections (Figure 5) which are pivoted to release the old gauntlet when a new gauntlet is inserted from the clean area. There is no break in the containment during the gauntlet changing operation.

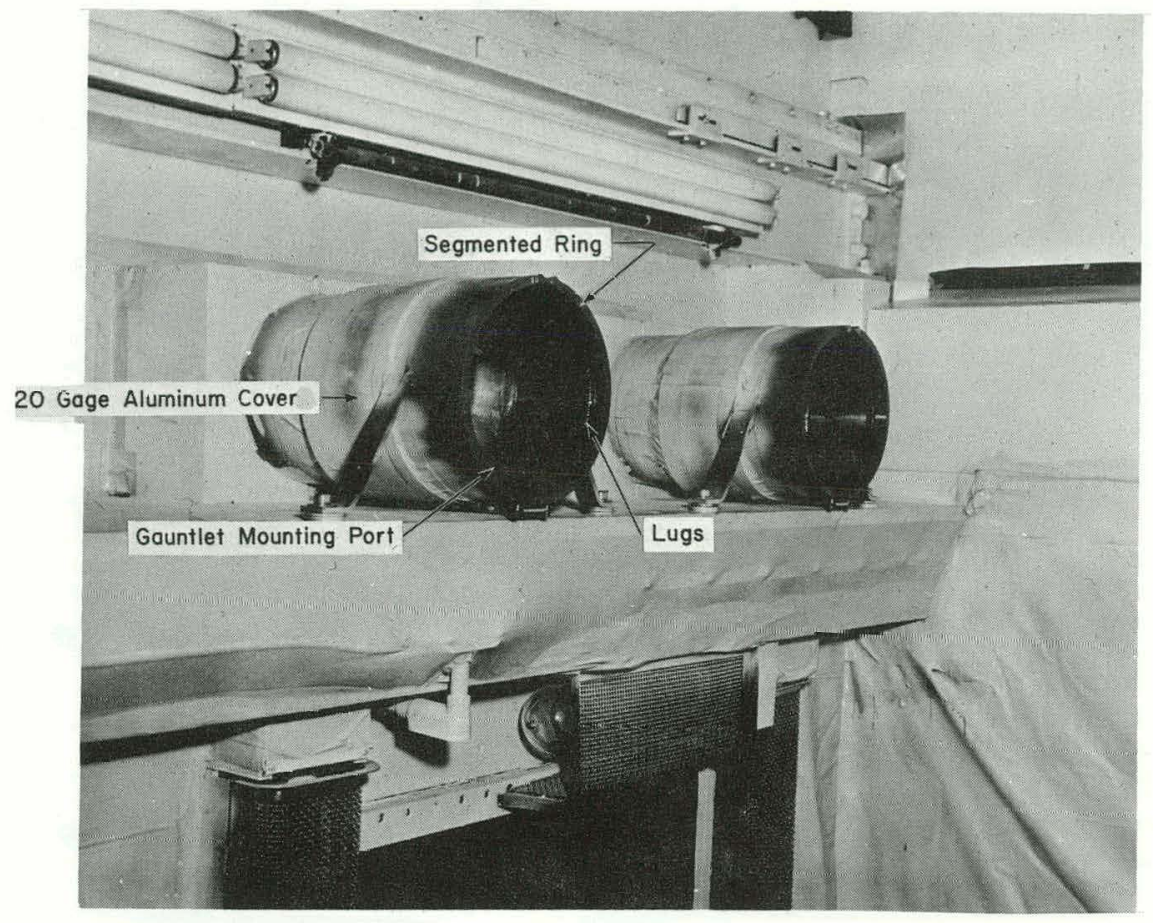

FIG. 5 GAUNTLET PORT INSTALLATION 